\title{
miRNA 200 Family Expression is a Strong Predictor for Recurrence Following Liver Resection for Breast Cancer Liver Metastases
}

\author{
Nicolae Bacalbasa ${ }^{1,2,3}$, Irina Balescu4, Veronica llie $^{2}$, Raluca Florea ${ }^{2}$, Andrei Sorop ${ }^{2}$, Vladislav Brasoveanu ${ }^{5}$, \\ Mihaela Vilcu ${ }^{1,3}$, Iulian Brezean ${ }^{1,3}$, Simona Dima ${ }^{2,5}$, Irinel Popescu ${ }^{5,6}$
}

"Carol Davila" University of Medicine and Pharmacy, Bucharest, Romania ${ }^{2}$ Center of Excellence in Translational Medicine, Fundeni Clinical Institute, Bucharest, Romania

"'Ion Cantacuzino" Clinical Hospital, Bucharest, Romania

4"Ponderas" Academic Hospital, Bucharest, Romania

"Dan Setlacec" Center of Gastrointestinal Disease and Liver Transplantation,

Fundeni Clinical Institute, Bucharest, Romania

"Titu Maiorescu" University, Bucharest, Romania

\section{Corresponding author:}

Nicolae Bacalbasa, MD

Dimitrie Racovita Street, no. 2

Bucharest, Romania

E-mail: nicolae_bacalbasa@yahoo.ro

\section{ABSTRACT}

Although only a small percent of breast cancer patients are diagnosed in metastatic stages, a significantly higher percent will develop disseminated recurrences at a certain point of their evolution, this event being responsible for a high number of cancer relate deaths. In recent years a particular attention was paid for identifying the factors which might be responsible for the development of metastatic disease. The current study included 27 patients submitted to surgery for breast cancer liver metastases in "Dan Setlacec" Center of Gastrointestinal Diseases and Liver Transplantation Fundeni Clinical Institute, Bucharest Romania. In all cases miRNA expression was studied in both tumoral and non-tumoral tissues. miRNA species which were proved to be supra-expressed in the tumoral areas included mainly the miRNA 200 family (miR-200c and miR-141). These results demonstrate that alterations in miRNA-200 family play a key role in development of breast cancer liver metastatic process. In the meantime miRNA family seems to be a strong predictor for recurrence following liver resection for breast cancer liver metastases. Therefore, these molecules might become an useful signature in identifying high risk breast cancer patients; moreover this analysis seem to provide a better selection of patients who could benefit most from hepatic resection for breast cancer liver metastases. In this way, a significant improvement of overall survival after liver resection is expected. In the meantime, miRNA analysis could also indicate which patients are less probably to benefit from surgery and could straighten them to other personalized therapeutic strategies.

Key words: breast cancer liver metastases, miRNA 200 family, liver resection

\section{INTRODUCTION}

Although only up to $10 \%$ patients with breast cancer present with metastatic disease from the initial time of diagnostic, a significantly higher number of cases with develop metastatic disease at a certain point of their evolution; this 
eventuality seems to be highly influenced by the tumor type, as well as by the lymph node status. Due to the fact that most cases presenting metastatic lesions will have a high clinical burden of metastatic disease (disseminated lesions involving different viscera) and they will become candidates only for palliative treatment (1-3).

Moreover, it seems that although patients diagnosed in similar stages of the disease, with similar histopathological subtypes receive standard treatment, their evolution is not quite similar; therefore, it has been suggested that there are other factors which might significantly influence the prognosis and the long term outcomes of such cases (4-6). These facts enabled the researchers to consider that the current classification of breast cancer is far for being perfect, an important number of cases receiving an ineffective or incomplete treatment. Therefore, these patients will experience recurrence in spite of an initially presumed good long term prognosis (7). This is why in the last decades it has been widely accepted that the concept that "one medicine fits for all patients with the same disease" is no longer valid and the concept of personalized cancer therapy was proposed (8).

In consequence, attention was focused on determining which the specific prognostic factors that might influence the risk of development of distant metastases are; once these factors are revealed, patients at high risk of developing systemic recurrences might receive a more specific treatment which might impede the apparition of disseminated metastatic disease $(1-3,9,10)$. A certain role in developing distant metastases irrespective of the origin of the primary tumor seems to be played by the presence of deregulated genes which seem to represent a prognostic factor in order to predict the occurrence of distant lesions (7,11-14). In the last decade a particular attention was paid for investigating the role of miRNA in breast cancer progression.

\section{MATERIAL AND METHOD}

Data of all patients submitted to hepatic resections for breast cancer liver metastases in "Dan Setlacec" Center of Gastrointestinal Diseases and Liver Transplantation Fundeni Clinical Institute, Bucharest Romania were retrospectively reviewed after obtaining the approval of the Ethical Committee (no.30504/ 17.10.2017). In the meantime, a written consent from all patients had been obtained before beginning the study. For each patient a numeric code was provided in order to maintain the confidentiality and anonymity of the patients. In all cases the specimens were obtained from both breast cancer liver metastases and normal hepatic tissues and were harvested each in $5 \mathrm{ml}$ RNA Later (Sigma) solution in order to prevent RNA destroy; after this all specimens were placed at $-85^{\circ} \mathrm{C}$ while for isolation of the RNA molecules the frozen tissues were stocked in RNAlater (Qiagen). The concentration of total RNA was determined by the spectrophotometric method using Nano-Drop 1000(Thermo Scientific). Checking out the samples was performed by capillary electrophoresis in acrylamide polymer. All used samples had a miRNA concentration higher of $200 \mathrm{ng} / \mathrm{ul}$ and a percentage concentration of miRNA higher than $25 \%$ of the entire quantity of isolated RNA. In order to select only the conform RNA samples, miRNA Microarray System with miRNA Complete Labeling and Hyb Kit (Agilent Technologies) and G3 Human miRNA Microarray Kit, Release 21, 8×60K (Agilent Technologies) protocols were used. Data was generated using Feature Extraction 12.0.3.1 soft. All quality reports were classified as "excellent" from technical point of view (fig. 1).

\section{RESULTS}

Based on the reports of quality and integrity of the RNA samples, 27 cases were considered eligible for the current study. The total RNA samples were analyzed based on the spectrophotometric studies while the miRNA samples were analyzed through capillary electrophoresis in acrylamide polymer. Data obtained are shown into table 1.

Data regarding miRNA expression obtained through microarray for the 27 patients with breast cancer liver metastases were analyzed using Gene Spring Software 14.8. miRNA expressions for tumoral and non-tumoral hepatic tissues are presented in fig. 2.

The next step was realizing a Heatmap report using data regarding miRNA levels in tumoral and non-tumoral liver tissues for both under-expressed and supraexpressed miRNA molecules. The under-expressed molecules included miR-122-5p, miR-122-3p, miR-3962, miR-5195, miR-486-5p, miR-6814, miR-885-5p while the supra-expressed ones included miR-141-3p, miR-183-5p, miR-196a, miR-4449, miR96-5p (fig. $3 a, b$ ).

Reported results were next corrected using Benjamini-Hochberg correction; therefore two species of supra-expressed miRNA molecules (miR-200c-3p şi miR-141-3p) and under-expressed molecules (miR-122$5 p$ şi miR-122-3p) were obtained. Comparative analysis of miRNA was realised by measuring their expression in metastatic tissue as well as in the resection margin's 


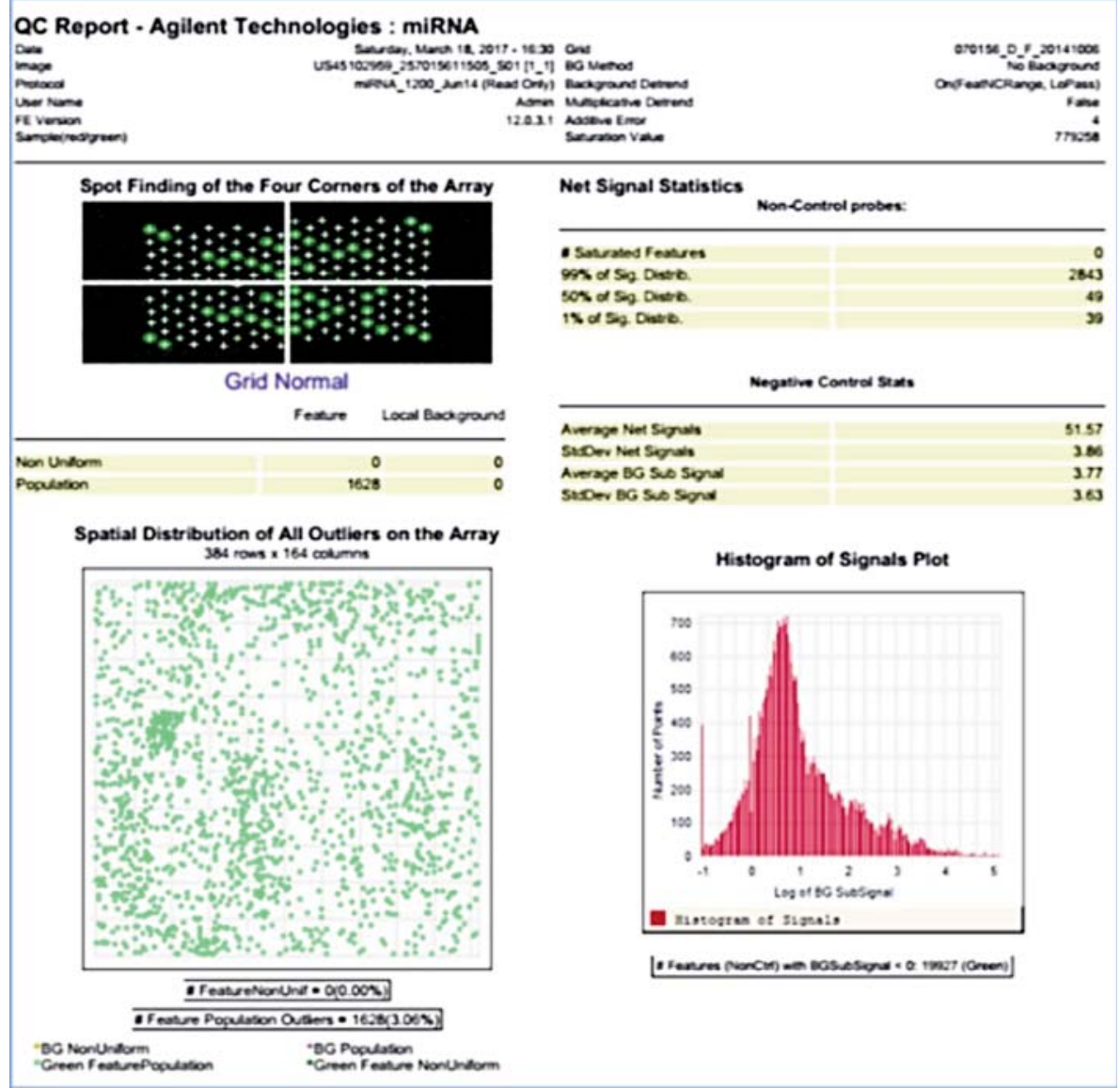

b

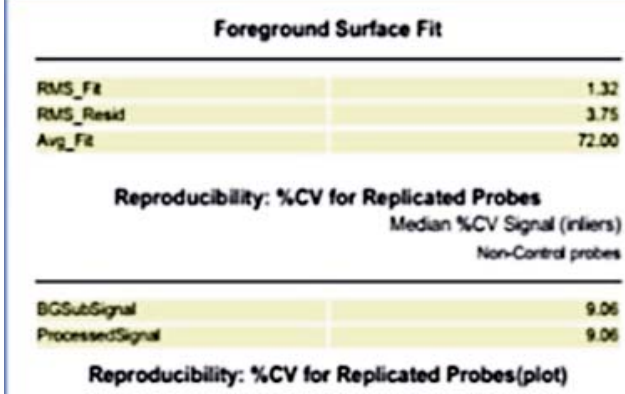

Spatial Distribution of Median Signals for each Row
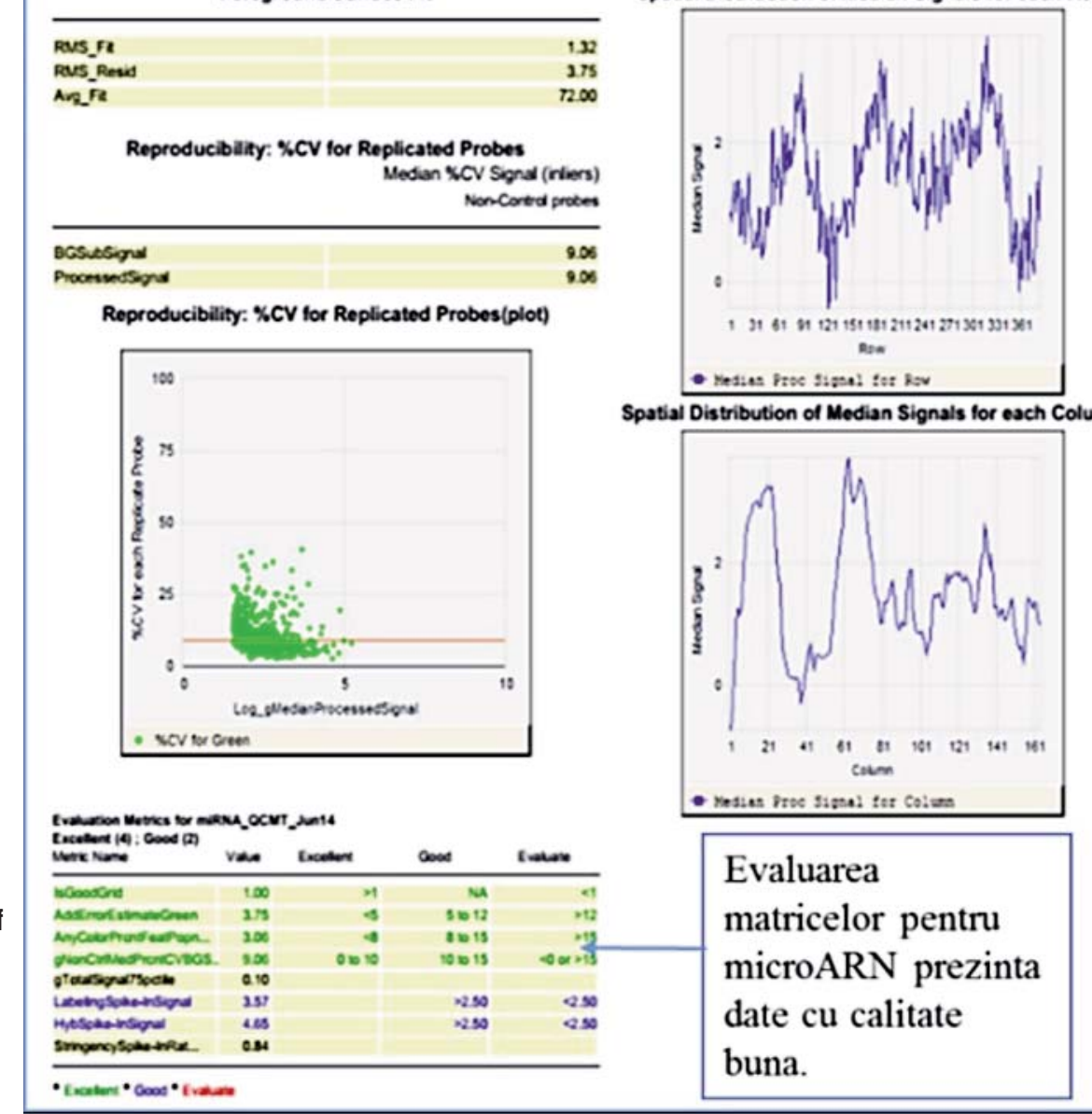

- Mesias hac stzal tes kor

Figure $1 \mathrm{a}, \mathrm{b}$ - The qualitative report of miRNA microarray 
Table 1 - Data regarding the RNA samples isolated from the 27 cases

\begin{tabular}{|c|c|c|c|}
\hline No. of case & Patient's code & Type of hepatic tissue & Concentration ng/ul \\
\hline 1 & GDA-5 & $\begin{array}{c}\text { tumoral } \\
\text { normal }\end{array}$ & $\begin{array}{c}847.48 \\
1246.01\end{array}$ \\
\hline 2 & FR-4 & $\begin{array}{c}\text { tumoral } \\
\text { normal }\end{array}$ & $\begin{array}{c}1985.97 \\
625.51\end{array}$ \\
\hline 3 & SM-23 & $\begin{array}{c}\text { tumoral } \\
\text { normal }\end{array}$ & $\begin{array}{c}1537.85 \\
955.03\end{array}$ \\
\hline 4 & NM-36 & $\begin{array}{c}\text { tumoral } \\
\text { normal }\end{array}$ & $\begin{array}{l}2015.50 \\
3500.89\end{array}$ \\
\hline 5 & NM-43 & $\begin{array}{c}\text { tumoral } \\
\text { normal }\end{array}$ & $\begin{array}{c}1360.49 \\
101.79\end{array}$ \\
\hline 6 & MM-8 & $\begin{array}{c}\text { tumoral } \\
\text { normal }\end{array}$ & $\begin{array}{c}581.61 \\
1856.53\end{array}$ \\
\hline 7 & EC-32 & $\begin{array}{c}\text { tumoral } \\
\text { normal }\end{array}$ & $\begin{array}{l}1548.86 \\
1610.30\end{array}$ \\
\hline 8 & MA-15 & $\begin{array}{c}\text { tumoral } \\
\text { normal }\end{array}$ & $\begin{array}{l}785.07 \\
299.74\end{array}$ \\
\hline 9 & AF-2 & $\begin{array}{c}\text { tumoral } \\
\text { normal }\end{array}$ & $\begin{array}{c}1067.51 \\
426.02\end{array}$ \\
\hline 10 & ND-41 & $\begin{array}{c}\text { tumoral } \\
\text { normal }\end{array}$ & $\begin{array}{c}409.46 \\
1199.11\end{array}$ \\
\hline 11 & AA-53 & $\begin{array}{c}\text { tumoral } \\
\text { normal }\end{array}$ & $\begin{array}{l}161.62 \\
391.17\end{array}$ \\
\hline 12 & IL-54 & $\begin{array}{c}\text { tumoral } \\
\text { normal }\end{array}$ & $\begin{array}{c}600.89 \\
1422.91\end{array}$ \\
\hline 13 & BD-56 & $\begin{array}{c}\text { tumoral } \\
\text { normal }\end{array}$ & $\begin{array}{l}436.13 \\
565.09\end{array}$ \\
\hline 14 & CDE-57 & $\begin{array}{c}\text { tumoral } \\
\text { normal }\end{array}$ & $\begin{array}{l}857.37 \\
572.13\end{array}$ \\
\hline 15 & LAG-58 & $\begin{array}{c}\text { tumoral } \\
\text { normal }\end{array}$ & $\begin{array}{l}653.88 \\
400.43\end{array}$ \\
\hline 16 & TA-59 & $\begin{array}{c}\text { tumoral } \\
\text { normal }\end{array}$ & $\begin{array}{c}1177.19 \\
503.77\end{array}$ \\
\hline 17 & SI-60 & $\begin{array}{c}\text { tumoral } \\
\text { normal }\end{array}$ & $\begin{array}{c}409.20 \\
1137.89\end{array}$ \\
\hline 18 & MC-61 & $\begin{array}{c}\text { tumoral } \\
\text { normal }\end{array}$ & $\begin{array}{r}454.76 \\
2183.25\end{array}$ \\
\hline 19 & VA-62 & $\begin{array}{c}\text { tumoral } \\
\text { normal }\end{array}$ & $\begin{array}{l}308.73 \\
124.24\end{array}$ \\
\hline 20 & IM-63 & $\begin{array}{c}\text { tumoral } \\
\text { normal }\end{array}$ & $\begin{array}{l}360.60 \\
955.67\end{array}$ \\
\hline 21 & BD-48 & $\begin{array}{c}\text { tumoral } \\
\text { normal }\end{array}$ & $\begin{array}{l}233.61 \\
395.43\end{array}$ \\
\hline 22 & ID-64 & $\begin{array}{c}\text { tumoral } \\
\text { normal }\end{array}$ & $\begin{array}{l}1145.22 \\
1231.05\end{array}$ \\
\hline 23 & SA-65 & $\begin{array}{c}\text { tumoral } \\
\text { normal }\end{array}$ & $\begin{array}{l}360.04 \\
743.63\end{array}$ \\
\hline 24 & VAM-25 & $\begin{array}{c}\text { tumoral } \\
\text { normal }\end{array}$ & $\begin{array}{c}895.22 \\
1015.13\end{array}$ \\
\hline 25 & $\mathrm{HS}-52$ & $\begin{array}{c}\text { tumoral } \\
\text { normal }\end{array}$ & $\begin{array}{l}310.77 \\
105.94\end{array}$ \\
\hline 26 & MC-35 & $\begin{array}{c}\text { tumoral } \\
\text { normal }\end{array}$ & $\begin{array}{l}463.60 \\
450.71\end{array}$ \\
\hline 27 & PM-66 & $\begin{array}{c}\text { tumoral } \\
\text { normal }\end{array}$ & $\begin{array}{c}1184.94 \\
130.38\end{array}$ \\
\hline
\end{tabular}



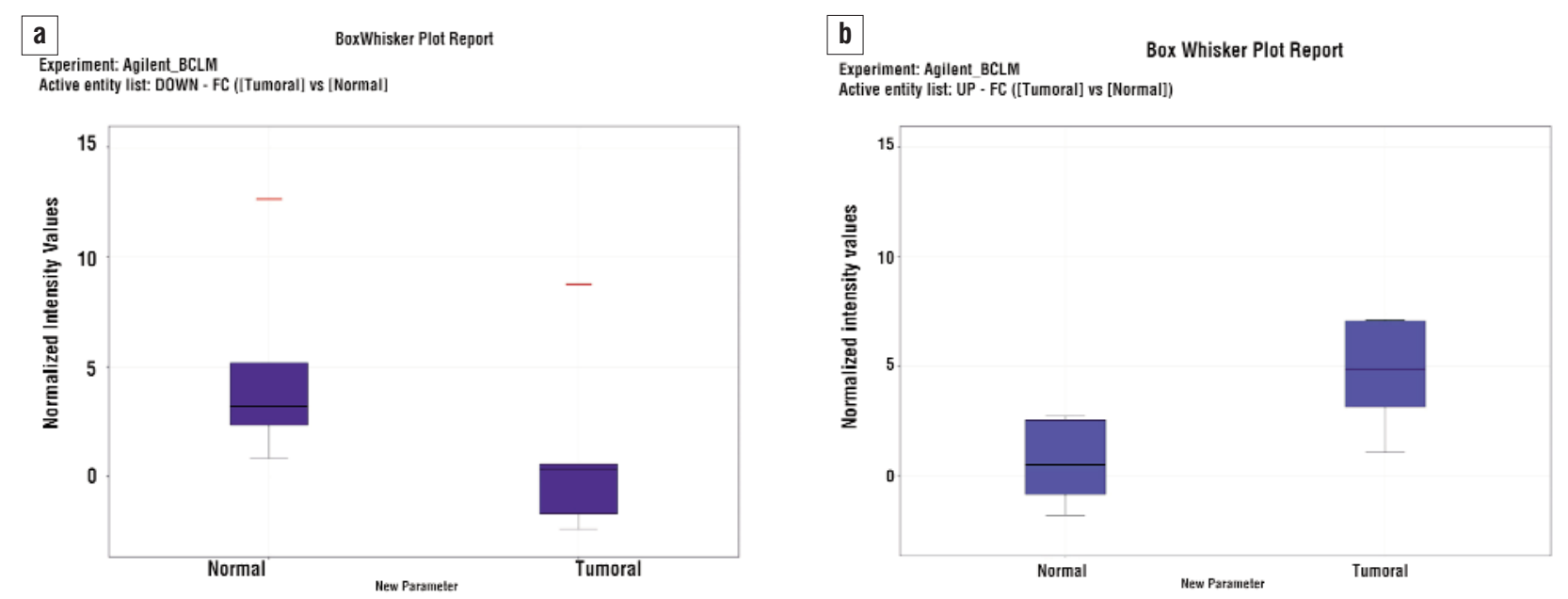

Figure 2 - miRNA levels obtained through microarray. a) BoxWhiskerReport of under-expression b) BoxWhiskerReport of supra-expression
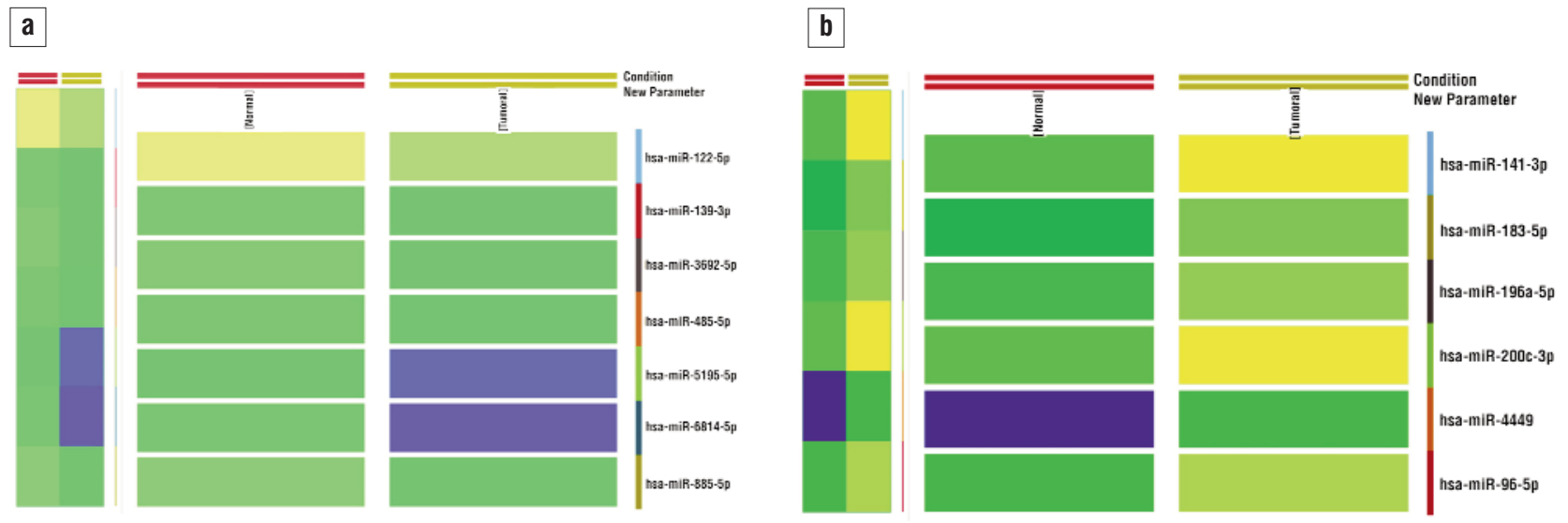

Figure 3 - a) Heatmap report - under-expressed miRNA. b) Heatmap report - supra-expressed miRNA

tissues. Data are shown in table 2. miRNA species which were proved to be under-expressed in metastatic hepatic areas (miR-122-5p and miR-122-5p) are in fact specific molecules for normal hepatic tissues while supra-expressed molecules (miR-200c and miR-141) are especially present in epithelial tissues.

\section{DISCUSSIONS}

The anarchic growth and spread of cells from a primary tumor is in fact the most common cause of death in cancer patients; at cellular level, these processes are characterized by the contact loss with the neighboring cells, increasing in this way their invasively character. This process is in fact represented by the epithelial to mesenchymal transition, a process in which epithelial cells experience a modification of their morphology, becoming more likely to mesenchymal cells. The resulting cells have a higher capacity of spread and developing distant tumoral lesions (15).

Table 2 - The main miRNA molecules which proved to be under- or supra-expressed in breast cancer liver metastases

\begin{tabular}{lcccc} 
ID & FC & AvgExpr & $\mathbf{t}$ & adj.P.Val \\
\hline hsa-miR-200c-3p & 17.54 & 29.6 & 4.2 & $8.8 E-03$ \\
\hline hsa-miR-141-3p & 21.68 & 27.9 & 4.2 & $8.8 \mathrm{E}-03$ \\
\hline hsa-miR-122-5p & 0.06 & $1,694.0$ & -3.9 & $1.9 \mathrm{E}-02$ \\
\hline hsa-miR-122-3p & 0.05 & 24.8 & -3.5 & $3.8 \mathrm{E}-02$ \\
\hline
\end{tabular}


Several studies have demonstrated that a central role in epithelial to mesenchymal transition is played by miRNA molecules, which seem to act as oncogenes or tumor suppressor (16).

microRNA (miRNA) are represented by short noncoding single stranded molecules of ARN composed by approximately 22 nucleotides which have the property of binding complementary sequences on target messenger RNA transcripts (17). This fact results in repression of the translational process and gene silencing; therefore miRNA regulate various biological functions such as cellular growth, differentiation and apoptosis, playing a central role in tumor progression $(17,18)$. Due to the fact that a single miRNA might regulate more different genes, it can become a very attractive therapeutic agent which might provide a promising way to control tumoral development. Moreover, it seems that in tumoral tissues miRNA can be overexpressed or under expressed when compared with normal tissues, this fact being able to explain the role of oncogene or tumor suppression gene of miRNA $(18,19)$.

According to McGuire's study, among miRNA molecules identified in breast cancer patients, there are few particles which play a key role in dissemination as well as in the metastatic cascade: while miR-199a, miR-214, miR-200a, miR-200b, miR-200c, miR-141 and miR-429 play a crucial step in tumor cell intravasation, miR-31 plays a central role in dissemination while miR-10b, miR-34-a, miR-155, miR-200a, miR-200b, miR-200c, miR-141 as well as miR-429 represent basic molecules in order to induce proliferation in the metastatic cellular clusters (20). This fact was also sustained by our findings, a higher expression of miR-200c and miR-141 being observed at the level of the liver metastases.

An interesting correlation was established between miR-200, E-caherin and the risk of developing distant metastases. It has been widely demonstrated that the invasiveness of a tumoral cell is inversely correlated with E-cadherin expression, its' overexpression suppressing invasion (21-23). However, E-cadherin expression is usually down-regulated by miRNA-9, miRNA-92 or mi-R200, the main mechanism which is responsible for this process consisting of direct suppression or inhibition of transcripting factors responsible for E-cadherin's regulation. Therefore increased levels of miR200, miRNA-9 or miRNA-92 are strongly correlated with decreased E-cadherin's activity, this fact inducing the apparition of distant metastases; however this correlation could not be demonstrated for cancers that had metastasized to the brain (24). When it comes to the live metastases, it seems that a higher level of miR200 could play a certain role, as demonstrated by our study too.

The miR-200 family is in fact composed by 5 molecules (miR-200a, miR-200b, miR-200c, miR-141 and miR-429) which has been related to breast cancer progression; initially this family inhibits the epithelial to mesenchymal transition, one of the initial steps in metastatic spread of the tumoral cells. Later on during this process, miR-200 influences the ability of colonization and growth in distant metastatic sites by influencing the reverse process, mesenchymal to epithelial transition (25-28). An interesting study which came to demonstrate the role of miR-200 family in the metastatic process in breast cancer patients was published by Karina Gravgaard in 2012. The authors demonstrated that miR-200 as well as miR-9 molecules report different expressions at different stages of progression of the malignant process; while in the initial stages of the disease the miR-200 family has been found to be down regulated, in metastatic stages they will be found in increased amounts (18).

A study conducted on the theme of differential expression of miRNA in breast cancer patients and a further correlation with lymph node status was conducted by Rask and published in 2014. The study included 43 fresh frozen samples of invasive ductal carcinoma selected from breast carcinoma biobank in Herlev Hospital, Denmark between 2005 and 2007 (7). In order to obtain a homogenous cohort, the authors included in the study only hormone positive tumors (defined as estrogen or progesterone receptor expression of at least $10 \%$ ) with negative status for HER2 overexpression; in the meantime all tumors measured between $1-3 \mathrm{~cm}$. when it came to the lymph node status, 20 patients presented at least one lymph node metastasis while the remaining 23 cases presented no lymph node metastasis. When analyzing the miRNA distribution among the two groups, the authors demonstrated that patients with positive lymph nodes reported 17miRNAs with a significant difference in terms of expression between the two groups (positive and negative lymph node groups), 8miRNAsbeing up-regulated and 9miRNAs being down-regulated in the positive lymph node group when compared to the negative lymph node group $(p<0.01)$. Among these molecules, up-regulation of miR-21 was significantly associated with breast cancer lymph node metastases why down-regulation of miR-355 was associated with a higher risk of recurrence when compared to patients presenting normal levels of miR-355. Moreover, the authors demonstrated that miR-486-5p, miR-139-5p, 
miR-223 and miR-455-3p were all found to be downregulated in cases presenting lymph node metastases. However, when investigating the other parameters (such as age at diagnostic or tumor size) no significant correlation could be established between them and miRNA expression patterns (7).

\section{CONCLUSIONS}

Although understanding metastatic breast cancer has significantly advanced during the last decades, development of disseminated tumoral recurrences remains the major cause of death in such patients. Over the last decade significant progress has been made in understanding the mechanisms of dissemination once microRNA molecules have been investigated. Also defined as "small RNAs which play big roles", these molecules seem to act as oncogenes, tumor suppresors or metastasis regulators which influence migration, invasion colonization or epithelial - mesenchymal transition (29). miRNA analysis in breast cancer patients play a crucial role in order to identify the subset of patients in whom development of distant metastases is to be expected. In consequence, these patients might benefit from a personalized therapeutic strategy. In conclusion, miRNA analysis represent a crucial step in order to identify patients who could benefit most from hepatic resection for breast cancer liver metastases, significant improvement of the overall survival after surgery being expected; therefore, patients presenting supra-expression of miRNA 200 family at the level of the hepatic lesions seem to have the best long term outcomes after liver resection for breast cancer liver metastases. Moreover, the same analysis might help the surgeon to exclude from surgical treatment cases in which resection does not seem to increase survival and propose this particular categoryof patients for other personalized therapeutic options.

\section{REFERENCES}

1. Cardoso F, Costa A, Norton L, Cameron D, Cufer T, Fallowfield L, et al. 1 st International consensus guidelines for advanced breast cancer (ABC 1). Breast 2012;21:242-52.

2. American Cancer Society. Global cancer facts and figures 2008. http://www. cancer.org/acs/groups/content/@epidemiologysurveilance/ documents/ document/acspc-027766.pdf

3. Peto R, Davies C, Godwin J, Gray R, Pan HC, Clarke M, et al. Comparisons between different polychemotherapy regimens for early breast cancer: meta-analyses of long-term outcome among 100,000 women in 123 randomised trials. Lancet 2012;379:432-44.

4. Bacalbasa N, Dima SO, Purtan-Purnichescu R, Herlea V, Popescu I. Role of surgical treatment in breast cancer liver metastases: a single center experience. Anticancer Res 2014;34:5563-8.

5. Bacalbasa N, Balescu I, Dima S, Popescu I. Long-term Survivors After Liver Resection for Breast Cancer Liver Metastases. Anticancer
Res 2015;35:6913-7.

6. Bacalbasa N, Balescu I, Dima S, Popescu I. The Role of Re-resection for Breast Cancer Liver Metastases-a Single Center Experience. Anticancer Res 2015;35:6877-80.

7. Rask L, Balslev E, Sokilde R, Hogdall E, Flyger H, Eriksen J, et al. Differential expression of miR-139, miR-486 and miR-21 in breast cancer patients sub-classified according to lymph node status. Cell Oncol (Dordr ) 2014;37:215-27.

8. Jain KK.Applications of Biotechnology in Oncology, DOI 10.1007/978-1-4614-9245-0_16, 671 C Springer Science+Business Media New York 2014. Chapter 16 Personalized Cancer Therapy

9. IARC. GLOBOCAN 2012: Estimated Incidence, Mortality and Prevalence Worldwide in 2012; 2014.

10. Tsuchiya S, Okuno Y, Tsujimoto G. MicroRNA: biogenetic and functional mechanisms and involvements in cell differentiation and cancer. J PharmacolSci 2006;101:267-70.

11. Eccles S, Paon L, Sleeman J. Lymphatic metastasis in breast cancer: importance and new insights into cellular and molecular mechanisms. ClinExp Metastasis 2007:24:619-36.

12. Grigoroiu M, Tagett R, Draghici S, Dima S, Nastase A, Florea R, et al. Gene-expression Profiling in Non-small Cell Lung Cancer with Invasion of Mediastinal Lymph Nodes for Prognosis Evaluation. Cancer Genomics Proteomics 2015;12:231-42.

13. Botezatu A, Bleotu C, Nastase A, Anton G, Bacalbasa N, Duda D, et al. Epigenetic Silencing of GNMT Gene in Pancreatic Adenocarcinoma. Cancer Genomics Proteomics 2015;12:21-30.

14. Mirancea GV, Morosanu AM, Carniciu S, Dima S, Bacalbasa N, Popescu I, et al. Relevant infrastructural alterations in a pancreatic neuroendocrine tumor: an insulinoma case. Rom J Morphol Embryol 2014;55:659-68.

15. Bracken CP, Gregory PA, Khew-Goodall Y, Goodall GJ. The role of microRNAs in metastasis and epithelial-mesenchymal transition. Cell Mol Life Sci 2009;66:1682-99.

16. Zhang $B$, Pan $X$, Cobb GP, Anderson TA. microRNAs as oncogenes and tumor suppressors. DevBiol 2007;302:1-12.

17. Kimbung S, Loman N, Hedenfalk I. Clinical and molecular complexity of breast cancer metastases. Semin Cancer Biol 2015;35:85-95.

18. Gravgaard KH, Lyng MB, Laenkholm AV, Sokilde R, Nielsen BS, Litman T, et al. The miRNA-200 family and miRNA-9 exhibit differential expression in primary versus corresponding metastatic tissue in breast cancer. Breast Cancer Res Treat 2012;134:207-17.

19. Iorio MV, Ferracin M, Liu CG, Veronese A, Spizzo R, Sabbioni S, et al. MicroRNA gene expression deregulation in human breast cancer. Cancer Res 2005;65:7065-70.

20. McGuire A, Brown JA, Kerin MJ. Metastatic breast cancer: the potential of miRNA for diagnosis and treatment monitoring. Cancer Metastasis Rev 2015;34:145-55.

21. VleminckX K, Vakaet L, Jr., Mareel M, Fiers W, van Roy F. Genetic manipulation of E-cadherin expression by epithelial tumor cells reveals an invasion suppressor role. Cell 1991;66:107-19.

22. Frixen UH, Behrens J, Sachs M, Eberle G, Voss B, Warda A, et al. Ecadherin-mediated cell-cell adhesion prevents invasiveness of human carcinoma cells. J Cell Biol 1991;113:173-85.

23. Navarro P, Gomez M, Pizarro A, Gamallo C, Quintanilla M, Cano A. A role for the E-cadherin cell-cell adhesion molecule during tumor progression of mouse epidermal carcinogenesis. J Cell Biol 1991;115: 517-33.

24. Bohl CR, Harihar S, Denning WL, Sharma R, Welch DR. Metastasis suppressors in breast cancers: mechanistic insights and clinical potential. J Mol Med (Berl) 2014;92:13-30.

25. Gregory PA, Bert AG, Paterson EL, Barry SC, Tsykin A, Farshid G, et al. The miR-200 family and miR-205 regulate epithelial to mesenchymal transition by targeting ZEB1 and SIP1. Nat Cell Biol 2008:10:593-601.

26. Birchmeier C, Birchmeier W, Brand-Saberi B. Epithelial-mesenchymal transitions in cancer progression. ActaAnat (Basel) 1996;156:217-26

27. Chaffer $\mathrm{CL}$, Weinberg RA. A perspective on cancer cell metastasis. Science 2011;331:1559-64.

28. Korpal M, Lee ES, Hu G, Kang Y. The miR-200 family inhibits epithelial-mesenchymal transition and cancer cell migration by direct targeting of E-cadherin transcriptional repressors ZEB1 and ZEB2. J BiolChem 2008;283:14910-4

29. Kim J, Yao F, Xiao Z, Sun Y, Ma L. MicroRnAs and metastasis: small RNAs play big roles. Cancer Metastasis Rev 2018;37:5-15. 